\title{
THE READINESS OF THE VILLAGE COMMUNITY "PASIRMULYA" TO DEVELOP A TOURIST HERITAGE DESTINATION COFFEE PUNTANG
}

\author{
Enggal Sriwardiningsih ${ }^{1 *}$, Yopy Maulana ${ }^{2}$, Martin Fieser ${ }^{3}$ \\ 'Management Department, BINUS Business School Undergraduate Program, Bina Nusantara University, \\ ${ }^{2}$ Faculty of Economics and Communication, Bina Nusantara University, ${ }^{3}$ International Marketing Department, \\ BINUS Business School Undergraduate Program, Bina Nusantara University, Jakarta Indonesia \\ *enggal@binus.ac.id
}

\begin{abstract}
Pasir Mulya village community has the potential to become a tourist destination village, but it has not been realized until now. Therefore, there needs to be analytical factors that become strengths, weaknesses, opportunities and threats about the potential of this village. The method used to use SWOT analysis by interviewing some local government officials in formulating tourism village strategy. The results of this research found that the readiness of Pasir Mulya village community has more strengths factor than weakness factor, opportunities factors than threats factors, defensive retrenchment strategy according to SWOT matrix, and aggressive position space matrix strategy through into a tourist destination village. Villagers and village officials should a manage of solidarity that is high in the image of a friendly village, develop a heritage from the Malabar radio station site and the Dutch historical site, and promote the coffee Arabica Puntang the coffee-winning organic coffee in Atlanta.
\end{abstract}

Keywords: Readiness, develop, tourist, heritage destination, village community

\section{BACKGROUND}

Goals The development of a tourist village is an area of attraction, public facilities, accessibility, interconnected communities and can be realized as interests (Okech, 2012). The tourist village is a place of residence in a small village, village or village unity (George et al., 2009; Irshad, 2010; Dorobantu \& Nistoreanu, 2012). Village tourism develops without making rural areas drastically changed into urban areas. A tourist site will be interesting if it has the uniqueness, culture, beauty, and handicrafts that become a target or tourist destination (George et al., 2009). Elements of a tourist building consisting of, the typical objects of, interesting materials of the area, accessibility and community service at tourist sites. The other side, service in tourist destinations needs investment, tourism industry, institutional, marketing. This is supported by the village tour experts is a means and benefit of the experience as a tourist (Pakurar \& Olah, 2008; Bailey, 2015).

The United Nations World Tourism Organization (UNWTO) encourages Indonesia to maximize the development of village-based tourism or tourist villages. In addition to attracting more tourists, the development of tourist villages also provides an impact of equitable distribution to the village level and raises the level of the economy of the community. Villagers should be aware and eager to develop tourism as a tool for health promotion, as well as preservation of local cultural values as uniqueness of tourist destination. The development of tourist village based on the wisdom of the village community must be prepared because the biggest challenge in developing the tourist village is the community's behavior such as hygiene, language, tidiness and other things (voaindonesia.com, 2018). According to purpose of Indonesia's government and UNWTO, one rural area near by Bandung city is Pasir Mulya village and the village seeks to develop its village into a tourist visiting village with its cultural wisdom and natural resources. Pasir Mulya village has an area of approximately 442 ha square.

The village of Pasir Mulya is divided into three hamlets consisting of twelve communities of residents, and forty-two group of neighborhoods. It population density are 5722 peoples into 1756 families. The village has a tremendous potential to be developed. One of the potential cultural heritage 
source is coffee Puntang. Coffee Puntang is the international winners at SCAA Festival at Atlanta USA. This village has a lot positive value such as people with high solidarity with each other, friendly attitude always reflected by the villagers towards the visiting guests, high quality of coffee grown using $100 \%$ organic, fertilizer to produce Arabic coffee quality, old Dutch heritage buildings in Indonesia when Indonesia people was controlled by the Netherlands and the radio station Malabar heritage as the greatest communication center in the Dutch era.

The most uniqueness from this village recently is the coffee from this village that people recognize as Puntang coffee bean (Kompas.co, 2016). The Puntang coffee harvest required facilities to support it as a tourist destination. Reciprocally, Local government of pasir Mulya realize their potential but lack of implementation and lack of design their strategic planning. Pasir Mulya will become the object of this research. Figure 1 below shows the location of the punted village on the map

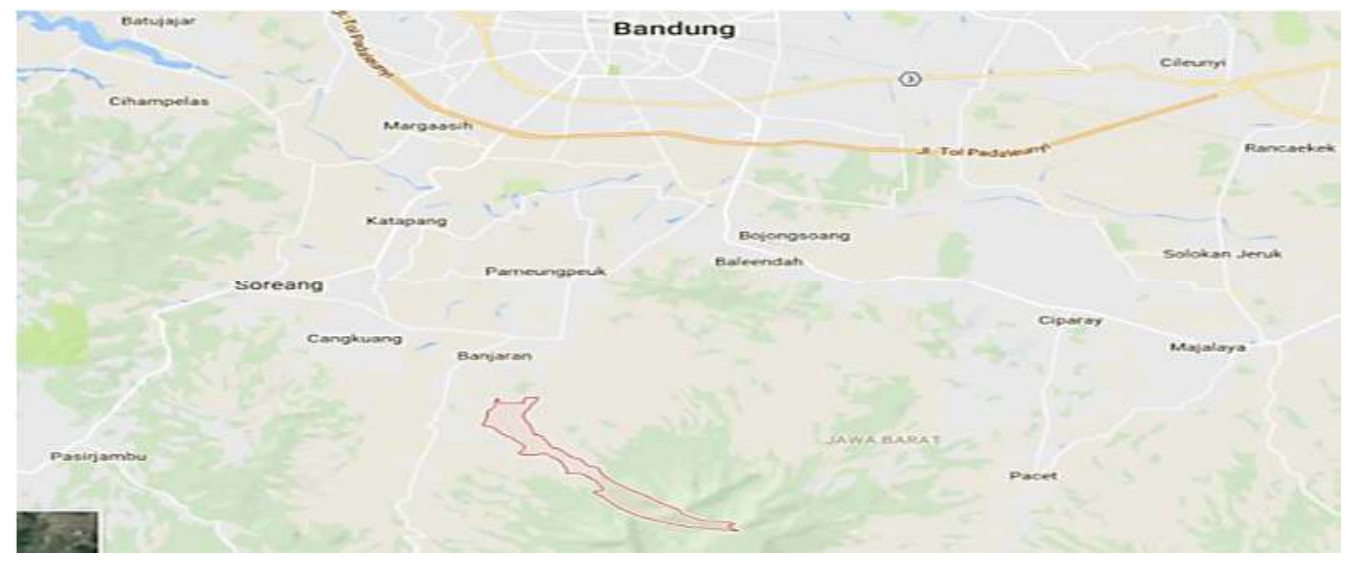

Figure 1. Map location of Pasir Mulya Banjaran Bandung West Java

Based on the main problem is how the readiness of this village to the village of tourist destination hence compiled the problem identification, in order to be taken strategic action decision to solve the problem.

1. How is the strength - weakness internal analysis of Pasir Mulya Government and Village?

2. How is the opportunity - threat external analysis of Pasir Mulya Government and Village?

3. How the proposed strategic model of rural tourism destination for the government of Pasir Mulya Village according to Matrix SWOT Analysis?

4. How the proposed strategic model of rural tourism destination for the government of Pasir Mulya Village according to Space Matrix Analysis?

\section{LITERATURE REVIEW}

According to business dictionary (2018), readiness states preparedness of persons, systems, or organizations to meet a situation and carry out s planned sequence of actions. This word based on thoroughness of the planning, adequacy and training of the personnel, supply and reserve of support services of systems.

It is difficult to form a precise definition of the term 'village' (Calatrava-Requena, 2016), commonly it is understood to mean a small area with small population which follows agriculture not only as an occupation but also as a way of life. Village community has passed evolution through the following stages: primitive village community, medieval village community and modern village community. In this way, the village is a community whose members have a sense of unity, close neighborhood relations, faith in religion, and a simple life in a joint family. Community development is not possible growth without cooperation upon factors: a) Topographical include land, water and climate. b) Economic include the condition of agriculture, rural economy and cottage industries. The farmer must be in a position to procure animals of good breed, good seeds, good manure and scientific implements. There should be cooperative societies for supplying capital, good seeds, implements and 
to arrange the sale of agricultural produce at reasonable prices. c) Social include peace, security, cooperation and intelligence etc.

Heritage and its preservation is a major concern around the world. In order to establish identities, as well as attracting visitors, the natural and cultural heritage is protected, conserved, managed and interpreted, by families, by cities, by nation states and at international level. Environmental and cultural heritage is now accepted as a major feature in business location, as the demand for quality of life becomes insistent (Howard, 2003). The heritage tourist destination is a geographical in small scale area with attraction, public facilities, accessibility, and interconnected communities and pairs the realization of tourism (George et al., 2009; Irshad, 2010; Dorobantu \& Nistoreanu, 2012; Okech, 2012). Tourism Products is a series of activities, that consist of services and benefits gained that form or constitute a person's overall experience as a tourist (Pakurar \& Olah, 2008; Smith (1994). Tourist Attractions is anything that has uniqueness, beauty, and value in the form of diversity of natural wealth, culture, man-made products that become the target or destination of tourists (George, 2009; Anuwichanont \& Mechinda, 2014). Rural tourism is a type of tourism product located in a village (or part of a village, such as a hamlet) or in some villages that form a unity of rural areas, developed without having to make rural areas change drastically into urban areas.

\section{METHOD}

This research approach used both deductive and inductive approaches. The deductive approach used self-administered questionnaire framework based on strengths, weaknesses, opportunities and threats indicators. Inductive approach (Kane \& Trochim, 2009) conducted the Pasir Mulya local government organization consist of Village headman, staffs in the organization structure and, Rural Forest Community (LMDH) organization. The observation was conducted in eight months focused on evaluating the readiness of the local government and organization through comprehensive perspective based on SWOT analysis of the organization and village as their purpose to become a heritage tourism destination. This research approach taken to analyze and evaluate in order to determine strategic steps to achieve predetermined readiness the village organization (Bhatia, 2012). The Pasir mulya government organization would be able to clearly discover the internal and external situation (David \& Carolina, 2011) and help them to determine strategic and tactical programs to help achieve long-term and short-term goals.

\section{RESULT AND DISCUSSION}

The results of the SWOT analyze were carefully measured and assessed. The assignment of the weight and rating were based on observation are as follows:

Table 1a. Swot Analysis

\begin{tabular}{|c|c|c|c|c|}
\hline & Criteria(s) & Weight & Rating & $\begin{array}{l}\text { Weight } \\
\text { Score }\end{array}$ \\
\hline Strengths & $\begin{array}{l}\text { 1. The landscapes of village are suitable for } \\
\text { trekking, camping, and outdoor activities } \\
\text { both individuals and groups. } \\
\text { 2. The main crop is Coffee by its inhabitants } \\
\text { 3. The local Arabica coffee become the top six } \\
\text { of } 74 \text { coffee species at Specialist Coffee event } \\
\text { in Atlanta, USA. } \\
\text { 4. People have high solidarity with each other. } \\
\text { 5. The attitude friendly towards the visiting are } \\
\text { reflected by the villagers. } \\
\text { 6. The Arabica coffee produce using } 100 \% \\
\text { organic. } \\
\text { 7. Malabar radio station site and other historical } \\
\text { sites of the Dutch heritage }\end{array}$ & $\begin{array}{l}0.06 \\
0.07 \\
0.08 \\
0.04\end{array}$ & $\begin{array}{l}3 \\
3 \\
4 \\
3\end{array}$ & $\begin{array}{l}0.18 \\
0.21 \\
0.32 \\
0.12\end{array}$ \\
\hline
\end{tabular}




\begin{tabular}{|c|c|c|c|c|}
\hline & $\begin{array}{l}\text { 8. Very beautiful spot photos with a historical } \\
\text { site on Puntang Mountain. } \\
\text { 9. Clean and abundant water resources flow } \\
\text { continuously. }\end{array}$ & $\begin{array}{l}0.03 \\
0.04\end{array}$ & $\begin{array}{l}3 \\
4\end{array}$ & $\begin{array}{l}0.09 \\
0.16\end{array}$ \\
\hline & Sub total & & +31 & 2.03 \\
\hline \multirow[t]{3}{*}{ Weaknesses } & $\begin{array}{l}\text { 1. Promotion Village tourism is still lacking. } \\
\text { 2. Only few public transport and facilities. } \\
\text { 3. Organizational structure does not match with } \\
\text { village tourism development yet. } \\
\text { 4. The main road is not well-established. } \\
\text { 5. The concept of rural tourism destination is } \\
\text { still not focus and well-organized yet. } \\
\text { 6. Lack support of central government for } \\
\text { development of Arabica coffee cultivation. }\end{array}$ & $\begin{array}{l}0.12 \\
0.08 \\
0.07 \\
\\
0.05 \\
0.05 \\
0.05\end{array}$ & $\begin{array}{l}4 \\
2 \\
2 \\
3 \\
2 \\
2\end{array}$ & $\begin{array}{l}0.48 \\
0.16 \\
0.14 \\
0.15 \\
0.10 \\
0.10\end{array}$ \\
\hline & Sub total & & -15 & 1.13 \\
\hline & TOTAL & 1.00 & & 3.16 \\
\hline
\end{tabular}

Table 1b. Swot Analysis

\begin{tabular}{|c|c|c|c|c|}
\hline & Criteria(s) & Weight & Rating & $\begin{array}{l}\text { Weight } \\
\text { Score }\end{array}$ \\
\hline \multirow[t]{2}{*}{ Opportunity } & $\begin{array}{l}\text { 1. Central Government of Indonesia has } \\
\text { determined tourism as one of the Top- } 10 \\
\text { priorities for } 2017 \text { Program. } \\
\text { 2. The interest of local investor starts to glance at } \\
\text { the coffee Puntang. } \\
\text { 3. The rural atmosphere is coffee plant } \\
\text { characteristics } \\
\text { 4. Social media through internet can promote the } \\
\text { village value proposition } \\
\text { 5. Puntang coffee as a winner at the SCAA } \\
\text { Coffee festival become an opportunity to build } \\
\text { International awareness market. }\end{array}$ & $\begin{array}{l}0.10 \\
0.12 \\
0.12 \\
0.12\end{array}$ & $\begin{array}{l}3 \\
4\end{array}$ & $\begin{array}{l}0.20 \\
0.36 \\
0.36 \\
0.48\end{array}$ \\
\hline & Sub total & & +14 & 1.52 \\
\hline \multirow[t]{3}{*}{ Threat } & $\begin{array}{l}\text { 1. There is no significant contribution on the } \\
\text { people's economy from coffee sector. } \\
\text { 2. Financial support from province government is } \\
\text { low. } \\
\text { 3. Adventure tourism activities are not well } \\
\text { managed that it potentially damaged the } \\
\text { existence of the natural environment. } \\
\text { 4. The villager is limitation of knowledge in } \\
\text { using the computer. } \\
\text { 5. Obstacles related to land acquisition will make } \\
\text { a road that will shorten the distance to the } \\
\text { Wangun village sustainably, from the previous } \\
6,2 \text { miles to } 1,25 \text { miles }\end{array}$ & $\begin{array}{l}0.12 \\
0.12 \\
0.07\end{array}$ & $\begin{array}{l}-4 \\
-2 \\
-2\end{array}$ & $\begin{array}{l}0.48 \\
0.24 \\
0.24\end{array}$ \\
\hline & Sub total & & -12 & 1.24 \\
\hline & TOTAL & 1.00 & & 2.72 \\
\hline
\end{tabular}




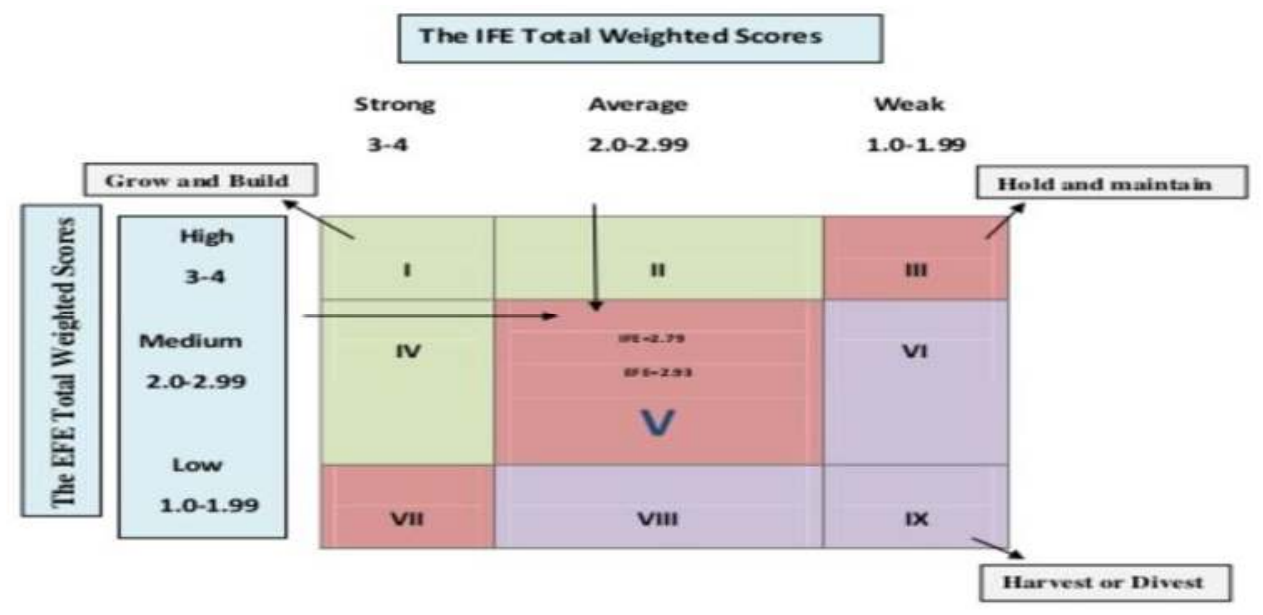

Figure 2. Matrix SWOT Analysis

According to IFE total weighted scores (IFE 0.9 and EFE 0.28), Pasir Mulya represents in harvest or divest position which is the weak position for the divisions. The strategies of Pasir Mulya village can do defensive retrenchment strategy (David, 2011). Retrenchment strategy in which it reorganizes its activities by reducing its assets \& costs. It means reorganization or turnaround strategy. When an organization applies retrenchment strategy, pressure is exerted from shareholders, media \& employees on the strategists who perform their functions with limited resources. Following are some of the activities that come under the retrenchment category such as: the product lines are pruned, the marginal businesses that are not profitable are closed down, the production \& other processes of the business organization are automated, and the expenses of the business are controlled in an effective manner. Some things that must be observed in carrying out this strategy (David, 2011):

a) The rural organization although has distinctive competencies but it is failed to accomplish its objectives \& goals consistently over a specified period of time.

b) The rural organization is regarded as one of the weaker competitors in the market.

c) Situation in which there is low profitability, poor employee morale, inefficiency \& pressure from the shareholders to make improvement in the performance of the business organization.

d) When the village devices of the rural organization have failed in achieving their objectives.

e) Quite rapid growth to large sized organization where there is need for major internal reorganization.

Table 2. Space Matrix

\begin{tabular}{|l|l|}
\hline Strength Position (SP) & Score \\
\hline 1.The landscapes of village are suitable for trekking, camping, and outdoor & 3 \\
activities both individuals and groups. & \\
2.The main crop is Coffee by its inhabitants & 4 \\
3.The local Arabica coffee become the top six of 74 coffee species at Specialist & 4 \\
Coffee event in Atlanta, USA. & 3 \\
4.People have high solidarity with each other. & 3 \\
5.The attitude friendly towards the visiting are reflected by the villagers. & 4 \\
6.The Arabica coffee produce using 100\% organic. & 3 \\
7.Malabar radio station site and other historical sites of the Dutch heritage & 3 \\
8.Very beautiful spot photos with a historical site on Puntang Mountain. & 4 \\
9.Clean and abundant water resources flow continuously. & +31 \\
\hline Sub total & \\
\hline Opportunity Position (OP) & 2 \\
\hline 1.Central Government of Indonesia has determined tourism as one of the Top-10 \\
priorities for 2017 Program.
\end{tabular}




\begin{tabular}{|c|c|}
\hline 4.Social media through internet can promote the village value proposition & 3 \\
\hline \multirow{2}{*}{$\begin{array}{l}\text { 5.Puntang coffee as a winner at the SCAA Coffee festival become an opportunity } \\
\text { to build International awareness market. }\end{array}$} & 4 \\
\hline & +14 \\
\hline \multicolumn{2}{|l|}{ Weaknesses Position (WP) } \\
\hline 1. Promotion Village tourism is still lacking. & -4 \\
\hline 2. Only few public transport and facilities. & -2 \\
\hline 3. Organizational structure does not match with village tourism development yet. & -2 \\
\hline 4. The main road is not well-established. & -3 \\
\hline 5. The concept of rural tourism destination is still not focus and well-organized yet. & -2 \\
\hline \multirow[t]{2}{*}{$\begin{array}{l}\text { 6. Lack support of central government for development of Arabica coffee } \\
\text { cultivation. }\end{array}$} & -2 \\
\hline & -15 \\
\hline \multicolumn{2}{|l|}{ Threat Position (TP) } \\
\hline \multirow{6}{*}{$\begin{array}{l}\text { 1. Promotion Village tourism is still lacking. } \\
\text { 2. Only few public transport and facilities. } \\
\text { 3. Organizational structure does not match with village tourism development yet. } \\
\text { 4. The main road is not well-established. } \\
\text { 5. The concept of rural tourism destination is still not focus and well-organized yet. } \\
\text { 6. Lack support of central government for development of Arabica coffee } \\
\text { cultivation. }\end{array}$} & -4 \\
\hline & -2 \\
\hline & -2 \\
\hline & \\
\hline & $\begin{array}{l}-2 \\
-2\end{array}$ \\
\hline & -12 \\
\hline \multicolumn{2}{|l|}{ Conclusion: } \\
\hline SP Average & $+31 / 10=+3.1$ \\
\hline OP Average & $+14 / 4=+5.5$ \\
\hline WP Average & $-15 / 5=-3.0$ \\
\hline TP Average & $-12 / 5=-2.4$ \\
\hline \multicolumn{2}{|l|}{ Vector Coordinates: } \\
\hline \multicolumn{2}{|l|}{$\mathrm{X}$ Axis $=-3.0+(+3.1)=+0.1$} \\
\hline \multicolumn{2}{|l|}{ Y Axis $=-3.6+(+5.5)=+1.9$} \\
\hline Coordinate $(+0.1,+1.9)$ so the vector poi & \\
\hline
\end{tabular}

SPACE Matrix Analysis is an analytical technique for strategic management planning. SPACE Matrix describe of strategic position and action evaluation. The analysis allows to create an idea of the appropriate strategy for government Pasir Mulya manage their village community. The analysis assesses the internal and external environment to design an appropriate strategy.

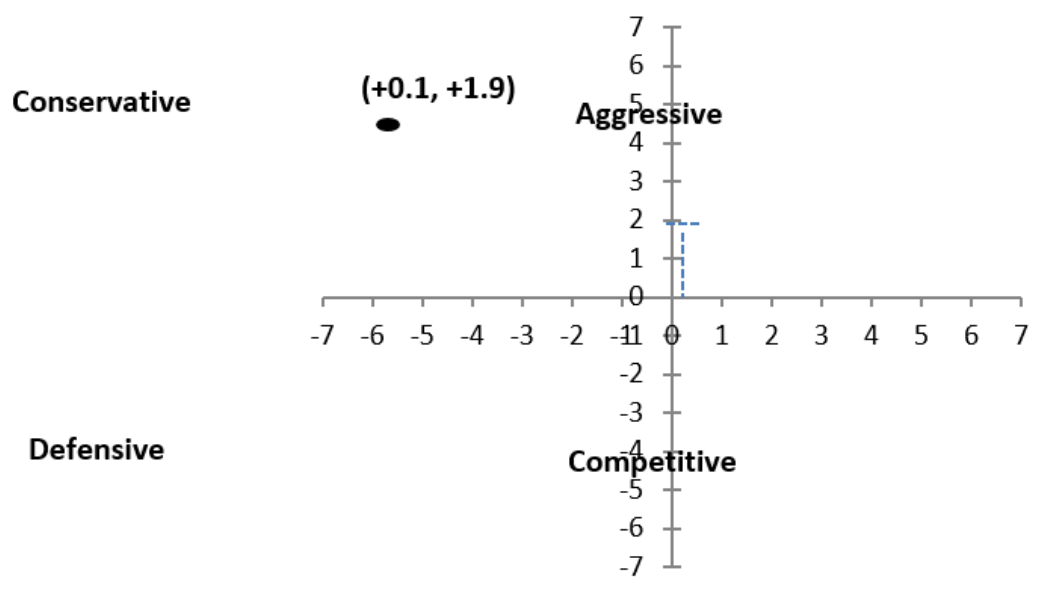

Figure 3. Space Matrix

SPACE analysis is used in strategic management for village officials involving important decisions made by village elders, village officials and Pasir Mulya village investors. According to this 
result, this village in an aggressive position. An aggressive positioning strategy must be done because the village has an attractive and relatively stable resource, the village has a competitive advantage and the village community can protect it. Another thing to do is to increase market share and focus on the competition of coffee products that are rampant today by maintaining the quality of coffee and competitiveness in the market. Critical factor faced is the possibility of entry of new competitors into the village by acquiring business ventures villagers.

From the analysis with the above approach, this study is to get some information so that researchers can provide insight and information that poured into the strategic program for the government of Pasir mulya associated with the goal of becoming a rural tourism destination. The result of the value propositions suggested to Pasir Mulya regarding to retrenchment aggressive strategy analysis are develop their Cultural heritage, develop the communication objectives as an international Coffee winners, Strengthen the culture their high solidarity and as a friendly village, Maintain and promote their High quality Coffee grown that is using $100 \%$ organic fertilizer to produce Arabica coffee quality, Create business plan for investor to rebuild the Malabar radio station site and historical sites of the Dutch.

\section{CONCLUSIONS}

Pasir Mulya is one of potential village to become a rural tourism destination. Local government is a determining factor in implementing a comprehensive development program and as the important actor to implement and monitoring activities to achieve the goal. It decision based on:

a) The strength factors are more than the weakness factors from internal resources of Pasir Mulya Government and Village.

b) The opportunities factors are more than threats external environment of Pasir Mulya Government and Village.

c) The strategic model of rural tourism destination for the government of Pasir Mulya Village according to Matrix SWOT proposes defensive retrenchment strategy.

d) The strategic model of rural tourism destination for the government of Pasir Mulya Village according to Space Matrix Analysis proposes aggressive strategy.

\section{LIMITATION}

In the research area of tourism destination, this study could not found yet that focus on analyzing the local government. Whereas, the government have important role to develop the strategic plan, implement and as an investor as well. Likewise, their commitment to consistently develop its territory is highly important.

\section{REFERENCES}

Anuwichanont J.and Mechinda P. (2014). "Examining the Impact of Brand Equity and Value Proposition of Ecological Destionation on Eco-touris Loyalty," Univers. J. Ind. Bus. Manag., vol. 2, no. 7, pp. 173-181.

Bailey D. (2015). "The Metrology of Organizational Performance: How Baldrige Standards Have Become the Common Language for Organizational Excellence Around the World," no. July. http://www.ses-standards.org, pp. 1-17

Bhatia A. (2012). "Swot Analysis of Indian Tourism Industry," Int. J. Appl. or Innov. Eng. Manag., vol. 2, no. 12 , pp. $44-49$.

Calatrava-Requena J. (2016) Origin and evolution of Rural Development concept and policies: From rural communities to territories. Conference Paper (PDF Available).

David F. R. and Carolina S. (2011). Strategic Management Concepts and Cases, vol. 28, no. 3 
David, F. R. (2011). Strategic Management: Concepts and Cases (13th ed.). Upper Saddle River, NJ: Prentice-Hall, Inc., p. 191.

Debarliev S. and Mitrovska S. (2016), "Creating Distinctive Value Proposition in Tourism by Business Model Tools: Case Study of the City of Ohrid," vol. 12, no. 35, pp. 82-104.

Dorobantu M.R. and Nistoreanu P. (2012). "Rural Tourism and Ecotourism, The Main Priorities in Sustainable Development Orientations of Rural Local Communities in Romania," Econ. Transdiscipl. Cogn., vol. 15, no. 1, pp. 3-10.

George W., Mair H. and Reid D.G (2009). Rural Tourism Development: Localism and Cultural Change. 2009.

Howard P. (2003). Heritage: Management, Interpretation, Identity, Social Science, A\&C Black, p. 278, Jun 16,

Irshad H. (2010). “Rural Tourism - an Overview October 2010,” J. Sustain. Tour., no. October, pp. 130.

Kane, M.W, \& Trochim (2009). "Concept Mapping for Applied Social Research," The SAGE Handbook of Applied Social Research Methods, pp. 435-474.

Okech R., Haghiri M, and George B. (2012). "Rural Tourism as a Sustainable Development Alternative: an Analysis With Special Reference To Luanda, Kenya," Cult. Rev. vol. 6, no. 3, pp. 38-54.

Mair H. and Reid D.G (2009). Rural Tourism Development: Localism and Cultural Change. 2009.

Pakurar M. and Olah J. (2008). "Definition of rural tourism and its characteristics in the northern great plain region,” System, vol. VII, pp. 777-782.

Smith S. L. J., (1994). “The tourism product,” Ann. Tour. Res., vol. 21, no. 3, pp. 582-595.

https://www.voaindonesia.com/a/indonesia-harus-maksimalkan-pengembangan-desa-wisata135821073/102280.html

http://www.businessdictionary.com/definition/readiness.html.

https://www.researchgate.net/publication/292617342_Origin_and_evolution_of_Rural_Development concept_and_policies_From_rural_communities_to_territories

https://travel.tempo.co/read/765017/kopi-gunung-puntang-juarai-kontes-kopi-di-atlanta-amerika. Kopi Gunung Puntang Juarai Kontes Kopi di Atlanta Amerika, Jumat, 22 April 2016 15:14 WIB 